\title{
Analisis Kinerja Keuangan Berbasis Akrual Atas Laporan Keuangan Pemerintah Daerah Kabupaten Konawe
}

\section{Oleh}

\author{
Arifuddin Mas'ud ${ }^{1}$, Erwin Hadisantoso ${ }^{2}$, Relis $^{3}$ \\ Email : Reliscenayang2013@gmail.com
}

\begin{abstract}
The purpose or this study was to determine the accrual-based financial performance on financial statements of the Konawe District government. The data used in this study is the Konawe District Government financial report data for the 2015-2016 fiscal year. The data collection techniques are library research and interviews. This research method is descriptive analysis, using several financial ratios, and regional financial dependence ratios.

The results of this study are the financial performance of the Konawe District Government in 2015 and 2016 in terms of liquidity ratios, solvency ratios and debt ratios which have shown good performance despite the decline in all ratios in 2016 but the value is still whit in safe limits, but ther are some of the ratios that describe the performance of Konawe District government are not good, such as regional financial independence ratios that are between 0 $25 \%$ classified as having an instructive relationship pattern which means the role of the central government is more dominant than the independence of local governments (regions that are not able to carry out blood autonomy financially). Regional financial dependency ratios are on an interval skale, 10.01-20.00\%. This means that the Regional Revenue has a considerable dependency to finance direct expenditure and the Konawe District Government is still dependent on sources of financial revenue from central and provincial government transfers.
\end{abstract}

Key words : Local Government Financial Statements, Accrual Based, Financial Ratios

\section{PENDAHULUAN}

Reformasi pengelolaan keuangan negara masih terus dilakukan secara berkelanjutan. Salah satu bentuk usaha berkelanjutan tersebut adalah dengan ditetapkanya Peraturan Pemerintah Republik Indonesia Nomor 71 Tahun 2010 tentang Standar Akuntansi Pemerintahan berbasis akrual. Peraturan Pemerintah Nomor 71 Tahun 2010 pasal 1 ayat (8) menyatakan bahwa Standar Akuntansi Pemerintahan Berbasis Akrual adalah standar akuntansi yang mengakui pendapatan, beban, aset, utang dan ekuitas dalam pelaporan finansial berbasis akrual, serta mengakui pendapatan, belanja, dan pembiayaan dalam pelaporan pelaksanaan anggaran berdasarkan basis kas yang ditetapkan dalam APBN/APBD.

Standar Akuntansi Pemerintahan yang ditetapkan dalam bentuk Peraturan Pemerintah Republik Indonesia Nomor 71 tahun 2010 tentang Standar Akuntansi Pemerintahan (SAP) bertujuan untuk memberikan pedoman pokok dalam penyusunan dan menyajikan laporan keuangan pemerintah baik pemerintah pusat maupun pemerintah daerah. Hal ini berarti bahwa pemerintah mempunyai kewajiban untuk dapat segera menerapkan SAP yang baru yaitu SAP berbasis akrual yang harus dilaksanakan selambat-lambatnya tahun 2015. Hal tersebut kemudian dituangkan dalam Peraturan Menteri Dalam Negeri Nomor 64 Tahun 2013 tentang Penerapan Standar Akuntansi Pemerintahan Berbasis Akrual pada pemerintah daerah.

Pemerintah Kabupaten Konawe adalah salah satu instansi yang juga menerapkan fungsi keuangan, walaupun sebagai instansi nonprofit yang tidak mencari keuntungan karena 
orientasinya adalah untuk pelayanan publik yang lebih baik tetap saja dituntut untuk mempunyai kinerja keuangan yang baik karena dengan kinerja keuangan yang baik artinya sama dengan pelaksanaan pengelolaan keuangan daerah dalam membiayai pembangunan dan memberikan pelayanan kepada masyarakat telah dilaksanakan dengan baik sesuai dengan perencanaan yang telah ditetapkan, disamping itu juga untuk pertanggungjawaban dan transparansi publik. Salah satu bentuk laporan dan pertanggungjawaban tersebut adalah Laporan Keuangan Pemerintah Daerah.

Salah satu komponen dari laporan keuangan pemerintah daerah yang digunakan untuk mengukur kinerja keuangan pemerintah daerah adalah laporan posisi keuangan yang kemudian dianalisis dengan menggunakan rasio keuangan seperti rasio likuiditas, rasio solvabilitas dan rasio leverege (utang) serta mengukur rasio kemandirian keuangan daerah dan rasio ketergantungan keuangan daerah berdasarkan laporan operasional.

Selain itu salah satu ciri utama daerah mampu dalam melaksanakan otonomi daerah adalah terletak pada kemampuan keuangan daerah untuk membiayai penyelenggaraan pemerintahan daerahnya dengan tingkat ketergantungan kepada pemerintah pusat mempunyai proporsi yang semakin mengecil dan diharapkan bahwa Pendapatan Asli Daerah (PAD) harus menjadi bagian terbesar dalam memobilisasi dana penyelenggaraan pemerintah daerah. Sehingga diperlukan analisis untuk mengukur tingkat kemandirian keuangan daerah serta tingkat ketergantungan keuangan daerah Pemerintah Kabupaten Konawe dengan menggunakan pendekatan analisis rasio kemandirian keuangan daerah dan rasio ketergantungan keuangan daerah. Berdasarkan uraian diatas, maka penulis tertarik mengangkat judul "Analasis Kinerja Keuangan Berbasis Akrual Atas Laporan Keuangan Pemerintahan Daerah Kabupaten Konawe Tahun Anggaran 2015-2016 ". Adapun rumusan masalah pada penelitian ini adalah Bagaimana Kinerja Keuangan berbasis akrual atas laporan keuangan pemerintah daerah Kabupaten Konawe yang diukur dengan rasio likuiditas, rasio solvabilitas, rasio utang (leverage) rasio kemandirian keuangan daerah dan rasio ketergantungan keuangan daerah ?, tujuan yang hendak di capai adalah untuk mengetahui Kinerja Keuangan Berbasis Akrual Atas Laporan Keuangan Pemerintah Kabupaten Konawe yang diukur dengan rasio likuiditas, rasio solvabilitas, rasio utang (leverage), rasio kemandirian keuangan daerah dan rasio ketergantungan keuangan daerah.

\section{KAJIAN PUSTAKA}

\section{Standar Akuntansi Pemerintahan}

Standar Akuntansi Pemerintahan adalah prinsip-prinsip akuntansi yang ditetapkan dalam penyusunan dan penyajian laporan keuangan pemerintah. Dengan demikan, SAP merupakan persyaratan yang mempunyai kekuatan hukum dalam upaya meningkatkan kualitas laporan keuangan di Indonesia (PP No. 24 Tahun 2005). Untuk memecahkan berbagai kebutuhan yang muncul dalam pelaporan keuangan, akuntansi dan audit dipemerintah, baik pemerintah pusat maupun pemerintah daerah di Republik Indonesia, diperlukan sebuah Standar Akuntansi Pemerintahan (SAP) yang kredibel yang dibentuk oleh sebuah komite SAP.

\section{Akuntansi Basis Akrual}

Akuntansi berbasis akrual adalah suatu basis akuntansi di mana transaksi ekonomi dan peristiwa lainnya diakui, dicatat dan disajikan dalam laporan keuangan pada saat terjadinya transaksi tersebut, tanpa memerhatikan waktu kas atau setara kas diterima atau dibayarkan (PSAP No. 1 Paragraf 8).

Menurut Erliana dan Rasdianto (2013), basis akuntansi ini merupakan basis akuntansi paling modest, karena dalam akuntansi akrual, informasi yang dihasilkan jauh lebih lengkap dan menyediakan informasi yang lebih rinci mengenai aset dan kewajiban. 


\section{Standar Akuntansi Pemerintahan Berbasis Akrual}

Peraturan Pemerintah Nomor 71 Tahun 2010 pasal 1 ayat (8) menyatakan bahwa Standar Akuntansi Pemerintahan Berbasis Akrual adalah standar akuntansi pemerintahan yang mengakui pendapatan, beban, aset, utang dan ekuitas dalam pelaporan finansial berbasis akrual, serta mengakui pendapatan, belanja, pembiayaan dalam pelaporan pelaksanaan anggaran berdasarkan basis kas yang ditetapkan dalam APBN/APBD.

SAP berbasis akrual diatur dan dijelaskan dalam Lampiran 1 Peraturan Pemerintah Nomor 71 Tahun 2010 tentang Standar Akuntansi Pemerintahan. Aturan tersebut berlaku sejak tanggal 22 Oktober 2010 dan dapat segera diterapkan oleh setiap entitas. Sementara itu, SAP berbasis kas menuju akrual yang diatur dan dijelaskan pada Lampiran II peraturan tersebut dapat diterapkan oleh entitas yang belum siap menerapkan SAP berbasis akrual sampai dengan jangka waktu paling lama 4 (empat) tahun setelah tahun anggaran 2010 yaitu tahun 2014. Artinya, pada tahun 2015 ini seluruh entitas pelaporan akuntansi sudah harus menerapkan akuntansi berbasis akrual.

\section{Laporan Keuangan Pemerintah Daerah}

Peraturan Pemerintah No. 71 Tahun 2010 paragraf 24 disusun untuk Laporan keuangan pemerintah daerah yang merupakan gabungan dari laporan keuangan SKPD yang ada dalam pemerintahan daerah itu sesuai Kerangka Konseptual menyediakan informasi yang relevan mengenai posisi keuangan dan seluruh transaksi yang dilakukan oleh suatu entitas pelaporan selama satu periode pelaporan.

\section{Tujuan Dan Manfaat Akuntansi Keungan Pemerintah Daerah}

Mahmudi (2016) Tujuan penyajian laporan keuangan bagi pemerintah daerah adalah:

a) Untuk memberikan informasi yang bermanfaat dalam pembuatan keputusan ekonomi, social dan politik,

b) Untuk alat akuntabilitas public,

c) Untuk memberikan informasi yang digunakan dalam mengevaluasi kinerja manajerial dan organisasi.

Mahmudi (2016) Manfaat penyajian laporan keuangan pemerintah daerah adalah:

a) Memberikan informasi keuangan untuk menentukan dan memprediksi kondisi kesehatan keuangan pemerintah terkait dengan likuiditas dan solvabilitasnya,

b) Memberikan informasi keuangan untuk menentukan dan memprediksi kondisi ekonomi suatu pemerintahan dan perubahan yang telah dan akan terjadi,

c) Memberikan informasi keuangan untuk memonitor kinerja, kesesuaiannya dengan peraturan perundang-undangan, kontrak yang telah disepakati, dan ketentuan lain yang telah disyaratkan,

d) Memberikan informasi untuk perencanaan dan penganggaran,

e) Memberikan informasi untuk mengevaluasi kinerja manajerial dan organisasional:

\section{Karakteristik Laporan Keuangan Pemerintah Daerah}

Peraturan Pemerintah No. 71 Tahun 2010 tentang Kerangka Konseptual Akuntansi Pemerintahan Paragraf 35-40 menyebutkan bahwa karakteristik kualitastif laporan keuangan adalah ukuran-ukuran normative yang perlu diwujudkan dalam informasi akuntansi, sehingga dapat memenuhi tujuannya. Keempat karakteristik berikut merupakan prasyarat normative yang diperlukan agar laporan keuangan pemerintah dapat memenuhi kualitas yang dikehendaki (Erliana dkk, 2015).

a) Relevan

b) Andal

c) Dapat dibandingkan 
d) Dapat dipahami

\section{Komponen Laporan Keuangan Pemerintah Daerah}

Sesuai PSAP No. 1 paragraf 14, komponen-komponen yang terdapat dalam satuset laporan keuangan terdiri dari laporan pelaksanaan anggaran (budgetary reports) dan laporan keuangan, sehingga seluruh komponen menjadi sebagai berikut (Erliana dkk, 2015):

a) Laporan Realisasi Anggaran (LRA)

b) Laporan Perubahan Saldo Anggaran Lebih (LPSAL)

c) Neraca

d) Aporan Operasional (LO)

e) Laporan Perubahan Ekuitas

f) Laporan Arus Kas

g) Catatan Atas Laporan Keuangan

\section{Kinerja Keuangan Pemerintah Daerah}

Mahsun (2016), Kinerja (performance) adalah gambaran mengenai tingkat pencapaian pelaksanaan suatu kegiatan/program/kebijakan dalam mewujudkan sasaran, tujuan, misi dan visi organisasi yang tertuang dalam strategic planning suatu organisasi.

\section{Rasio Keuangan}

\section{a. Definisi Rasio Keuangan}

Kasmir (2008:104), definisi rasio keuangan merupakan indeks yang menghubungkan dua angka akuntansi dan diperoleh dengan membagi satu angka dengan angka lainnya.

\section{b. Jenis-Jenis Rasio Keuangan}

a) Rasio Likuiditas menunjukkan kemampuan pemerintah daerah untuk memenuhi kewajiban jangka pendeknya.

b) Rasio Solvabilitas dapat digunakan untuk melihat kemampuan pemerintah daerah dalam memenuhi semua kewajibannya, baik kewajiban jangka pendek maupun jangka panjang.

c) Rasio utang sangat penting bagi kreditor dan calon kreditor potensial pemerintah daerah dalam membuat keputusan pemberian kredit. Rasio-rasio ini akan digunakan oleh kreditor untuk mengukur kemampuan pemerintah daerah dalam membayar utangnya.

d) Rasio Kemandirian Keuangan Daerah menunjukkan tingkat kemampuan pemerintah daerah dalam membiayai sendiri kegiatan pemerintahan, pembangunan dan pelayanan kepada masyarakat yang telah membayar pajak dan retribusi sebagai sumber pendapatan yang diperlukan daerah.

e) Rasio ketergantungan keuangan daerah dihitung dengan cara membandingkan jumlah pendapatan transfer yang diterima oleh penerimaan daerah dengan total penerimaan daerah. Semakin tinggi rasio ini maka semakin besar tingkat ketergantungan pemerintah daerah terhadap pemerintah pusat dan atau pemerintah propinsi, Sedangkan dalam menilai ketergantungan keuangan daerah (KKD) dengan menggunakan skala.

\section{Kerangka Pikir}

Untuk mengetahui kinerja suatu pemerintah adalah dengan melakukan analisis laporan keuangan terhadap anggaran yang telah ditetapkan dan dilaksanakan. Kinerja keuangan tercermin dari laporan keuangan neraca, laporan realisasi anggaran/ laporan operasional dan laporan arus kas. Analisis laporan keuangan merupakan kegiatan untuk menginterprestasikan angka-angka dalam laporan keuangan dalam rangka menilai kinerja keuangan yang hasil analisis tersebut akan digunakan sebagai dasar pengambilan keputusan ekonomi, sosial dan politik. Teknik yang paling 
banyak digunakan untuk menganalisis laporan keuangan adalah analisis rasio keuangan. Analisis rasio keuangan adalah suatu ukuran untuk mengidentifikasi ciri-cirikeuangan berdasarkan laporan keuangan yang tersedia. Dalam penelitian ini laporan keuangan yang digunakan untuk mengukur kinerja keuangan pemerintah Kabupaten Konawe adalah berdasarkan Laporan Posisi Keuangan (Neraca) dengan menggunakan rasio likuiditas, rasio solvabilitass dan rasio utang (Leverage). Serta mengukur kinerja keuangan berdasarkan laporan operasional dengan menggunakan rasio kemandirian keuangan daerah dan rasio ketergantungan keuangan daerah.

Upaya pemerintah untuk meningkatkan transparansi dan akuntabilitas pengelolaan keuangan negara salah satunya adalah dengan melakukan pengembangan kebijakan akuntansi pemerintahan berupa standar akuntansi pemerintahan (SAP) berbasis akrual yang bertujuan untuk memberikan pedoman pokok dalam penyusunan dan menyajikan laporan keuangan pemerintah baik pemerintah pusat maupun pemerintah daerah yang ditetapkan dalam bentuk eraturan Pemerintah Republik Indonesia Nomor 71 tahun 2010 tentang Stanndar Akuntansi Pemerintahan (SAP). Hal ini berarti bahwa pemerintah mempunyai kewajiban untuk dapat segera menerapkan SAP yang baru yaitu SAP berbasis akrual yang harus dilaksanakan selambat-lambatnya tahun 2015.

\section{Skema 2.1 Kerangka Pikir Penelitian}

\section{STUDI TEORITIS}

- Kinerja Keuangan Pemerintah Daerah, (Mahsun, 2016)

- Peraturan Pemerintah No. 71 Tahun 2010, tentang Standar Akuntansi Pemerintahan.

- Akuntansi Berbasis Akrual, (Bastian, 2010)

- Laporan Keuangan Pemerintah Daerah, (Erliana, dkk, 2015)

- Rasio Keuangan Pemerintah Daerah, (Mahmudi, 2016)

\section{STUDI EMPIRIS}

1. Penelitian Terdahulu

- Nurhayati(2016)

- Fathiyah dan Masnun (2017)

2. Fenomena Secara nominal terjadi peningkatan terhadap total asset pemerintah daerah kabupaten konawe sebesar $16,32 \%$, tetapi dalam hal proporsi asset tetap mengalami penurunan. Disamping itu kewajiban pemerintah daerah kabupaten konawe meningkat sebesar $368,1 \%$ akan mempengaruhi kemampuan pemerintah dalam menjamin total kewajibannya dengan menggunakan total asetnya yang hanya meningkat sebesar $16,32 \%$. 


\section{METODE PENELITIAN}

Objek dari penelitian ini adalah Laporan Keuangan Pemerintahan Daerah Kabupaten Konawe, Penelitian ini dilakukan pada Badan Pengelolaan Keuangan dan Aset Daerah Pemerintah Kabupaten Konawe, Lokasi di Jl. Inolobunggaadue II No. 1 Unaaha.

Jenis data yang digunakan dalan penelitian adalah kualitatif dan kuantitatif. Sumber data yang digunakan dalam penelitian ini adalah data primer dan sekunder. Dalam penelitian ini tekhnik yang digunakan untuk mengumpulkan data adalah (1). Wawancara, Wawancara (Interview) yaitu metode pengumpulan data yang diperoleh dengan cara mengajukan pertanyaan secara langsung kepada bagian keuangan pada Badan Pengelola Keuangan dan Aset Daerah Kabupaten Konawe (2) Studi Kepustakaan yaitu mengumpulkan data dan informasi yang dibutuhkan dan diperoleh dari berbagai referensi literatur, jurnal-jurnal media cetak, dokumen arsip, dan bacaan lainnya yang berkaitan dengan masalah dalam penelitian yang dapat digunakan sebagai landasan teori dan alat untuk melakukan analisis.

Metode analisis yang digunakan dalam penelitian ini adalah metode analisis deskriptif kuantitatif yaitu dengan menetapkan konsep perhitungan rasio keuangan dalam mengukur kinerja keuangan terhadap Laporan Keuangan Pemerintah Daerah Kabupaten Konawe tahun anggaran 2015-2016 dengan menggunakan rasio-rasio sebagai berikut:

\section{Rasio Likuiditas}

Rasio likuiditas menunjukkan kemampuan pemerintah daerah untuk memenuhi kewajiban lancarnya dengan menggunakan aset lancarnya. Untuk menganalisis rasio likuiditas dapat dilakukan dengan menggunakan rasio-rasio berikut:

a) Rasio Lancar (Current Ratio)

Rasio lancar membandingkan antara aktiva lancar yang dimiliki pemerintah daerah pada tanggal neraca dengan utang jangka pendekRasio lancar dirumuskan sebagai berikut:

$$
\text { Rasio Lancar }=\frac{\text { Aktiva Lancar }}{\text { Utang Lancar }} \times 100 \%
$$

b) Rasio Kas (Cash Ratio)

Rasio kas membandingkan antara kas yang tersedia dalam pemerintah daerah ditambah efek yang dapat segera diuangkan (Investasi Jangka Pendek) dibagi dengan utang lancar. Rasio kas dirumuskan sebagai berikut:

c) Rasio Cepat (Quick Rasio)

$$
\text { Rasio Kas }=\frac{\text { Kas }+ \text { Efek }}{\text { Utang Lancar }} \times 100 \%
$$

Rasio cepat membandingkan antara aktiva lancar setelah dikurangi persediaan dengan utang lancar. Rasio cepat dirumuskan sebagai berikut:

\section{Rasio Solvabilitas}

$$
\text { Rasio Cepat }=\frac{\text { Aktiva Lancar }- \text { Persediaan }}{\text { Utang Lancar }} \times 100 \%
$$

Rasio Solvabilitas dapat digunakan untuk melihat kemampuan pemerintah daerah dalam memenuhi semua kewaibannya, baik kewajiban jangka pendek maupun jangka panjang. Rasio solvabilitas dirumuskan sebagai berikut:

\section{Rasio Utang (Leverage Ratio)}

$$
\text { Rasio Solvabilitas }=\frac{\text { Total Aktiva }}{\text { Total Utang }} \times 100 \%
$$

Rasio utang sangat penting bagi kreditor dan calon kreditor potensial pemerintah daerah dalam membuat keputusan pemberian kredit. Terdapat beberapa jenis rasio utang, antara lain:

a) Rasio Utang Terhadap Ekuitas (Total Debt to Equity Ratio) 
Rasio ini digunakan untuk mengetahui bagian dari setiap rupiah ekuitas dana yang dijadikan jaminan untuk keseluruhan utang. Rasio ini dirumuskansebagai berikut:

$$
\text { Rasio Utang Terhadap Ekuitas }=\frac{\text { Total Utang }}{\text { Jumlah Ekuitas Dana }} \times 100 \%
$$

b) Rasio Utang Terhadap Aset Modal (Total Debt to Total Capital Assets)

Rasio ini digunakan untuk mengetahui berapa bagian aset modal yang dapat digunakan untuk menjamin utang. Aset modal dalam hal ini diproksikan dengan aset tetap. Rasio ini dirumuskan sebagai berikut:

$$
\text { Rasio Utang Terhadap Aset Modal }=\frac{\text { Total Utang }}{\text { Total Aset Modal }} \times 100 \%
$$

\section{Rasio Kemandirian Keuangan Daerah}

Rasio kemandirian menggambarkan ketergantungan daerah terhadap sumber dana eksternal. Rasio kemandirian dirumuskan sebagai berikut:

$$
\text { Rasio Kemandirian Daerah }=\frac{\text { Pendapatan Asli Daerah }}{\text { Transfer Pusat }+ \text { Provini }+ \text { Pinjaman }} \times 100 \%
$$

\section{Rasio Ketergantungan Keuangan Daerah}

Rasio ketergantungan keuangan daerah dihitung dengan cara membandingkan jumlah pendapatan transfer yang diterima oleh penerimaan daerah dengan total penerimaan daerah. Rumus yang digunakan sebagai berikut:

$$
\begin{aligned}
& \text { Pendapatan Transfer } \\
& \text { Rasio Ketergantungan Keuangan Daerah }=\longrightarrow \times 100 \% \\
& \text { Total Pendapatan Daerah }
\end{aligned}
$$

\section{HASIL PENELITIAN DAN PEMBAHASAN}

\section{Hasil penelitian}

Kinerja keuangan Pemerintah Daerah Kabupaten Konawe diukur dengan menggunakan rasio keuangan. Adapun rasio keuangan yang digunakan adalah Rasio Likuiditas, Rasio Solvabilitas, Rasio Utang (leverage) pada Laporan Posisi Keuangan serta mengukur Rasio Kemandirian Keuangan Daerah Dan Rasio Ketergantungan Keuangan Daerah pada Laporan Operasional, masing-masing rasio akan diuraikan dibawah ini:

\section{a. Rasio Likuiditas}

Rasio likuiditas (liqidity ratio) adalah rasio yang menggambarkan kemampuan pemerintah daerah dalam melunasi kewajiban jangka pendeknya dengan menggunakan aset lancarnya. Rasio likuiditas Pemerintah Daerah Kabupaten Konawe dihitung dengan menggunakan rasio lancar (current ratio), rasio cepat (quick ratio), dan rasio kas (cash rastio) yang disajikan dibawah ini:

a) Rasio lancar (current ratio)

Rasio lancar menunjukkan kemampuan pemerintah daerah dalam membayar utang yang segera harus dibayar dengan aset lancarnya. Berdasarkan data dari tabel diatas, maka rasio lancar dapat dihitung dengan rumus sebagai berikut:

$$
\text { Rasio Lancar }=\frac{\text { Aktiva Lancar }}{\text { Utang Lancar }} \times 100 \%
$$

Dengan menggunakan data tabel 1 diatas maka aset lancar terhadap utang lancar Pemerintah Daerah Kabupaten Konawe tahun 2015-2016 adalah sebagai berikut:

$$
\text { 45.939.435.597,70 }
$$

Tahun $2015=\frac{}{14.716 .194 .5 \% 1,17} \times 100 \%=3,12 \%$

$$
\text { 14.716.194.591,17 }
$$




$$
\text { Tahun } 2016=\frac{68.487 .642 .904,95}{35.619 .117 .459,41} \times 100 \%=1,92 \%
$$

Berdasarkan data diatas terlihat bahwa untuk tahun 2015 aset lancar sebesar Rp.45.939.435.597,70 dibandingkan dengan utang lancar sebesar Rp.14.716.194.591,17 dikali 100\% sehingga rasio lancar menjadi 3,12\%, untuk tahun 2016 aset lancarnya meningkat sebesar Rp.68.487.642.904,95 dan utang lancarnya meningkat sebesar Rp.35.619.117.459,41 dikali 100\% sehingga rasionya menjadi 1,92\%.

b) Rasio kas (cash ratio)

Rasio kas menunjukkan kemampuan pemerintah daerah dalam membayar utang yang segera harus dibayar dengan kas yang tersedia dan efek yang dapat segera diuangkan dengan rumus sebagai berikut:

$$
\text { Rasio Kas }=\frac{\text { Kas }+ \text { Efek }}{\text { Utang Lancar }} \times 100 \%
$$

Dengan menggunakan data tabel 4.1 diatas maka kas ditambah efek terhadap utang lancar Pemerintah Daerah Kabupaten Konawe tahun 2015-2016 adalah sebagai berikut:

$$
\begin{aligned}
& \text { Tahun } 2015=\frac{25.729 .628 .125,63}{14.716 .194 .591,17} \times 100 \%=1,75 \% \\
& \text { Tahun } 2016=\frac{38.409 .217 .144,39}{35.619 .117 .459,41} \times 100 \%=1,08 \%
\end{aligned}
$$

Berdasarkan data diatas terlihat bahwa untuk tahun 2015 kas dan efek sebesar Rp.25.729.628.125,63 dibandingkan dengan utang lancar sebesar Rp.14.716.194.591,17 dikali 100\% sehingga rasio lancar menjadi 1,75\%, untuk tahun 2016 kas dan efek meningkat sebesar Rp.38.409.217.144,39 dan utang lancarnya meningkat sebesar Rp.35.619.117.459,41 dikali 100\%, sehingga rasio kas menjadi 1,08\%.

c) Rasio Cepat (quick ratio)

Rasio cepat menunjukkan kemampuan pemerintah daerah dalam membayar utang yang segera harus dibayar dengan menggunakan aset lancar dikurangi persediaan, dengan rumus sebagai berikut:

$$
\text { Rasio Cepat }=\frac{\text { Aktiva Lancar }- \text { Persediaan }}{\text { Utang Lancar }} \times 100 \%
$$

Dengan menggunakan data tabel 1 diatas maka aset lancar terhadap utang lancar Pemerintah Daerah Kabupaten Konawe tahun 2015-2016 adalah sebagai berikut:

$$
\begin{aligned}
\text { Tahun } 2015 & =\frac{45.939 .435 .597,70-5.705 .242 .184,00}{14.716 .194 .591,17} \times 100 \% \\
& =\frac{40.234 .193 .431,70}{14.716 .194 .591,17} \times 100 \%=2,73 \% \\
\text { Tahun } 2016 & =\frac{68.487 .642 .904,95-5.683 .327 .333,00}{35.619 .117 .459,41} \times 100 \%
\end{aligned}
$$




$$
=\frac{62.804 .315 .571,95}{14.716 .194 .591,17} \times 100 \%=1,76 \%
$$

Berdasarkan data diatas terlihat bahwa untuk tahun 2015 aset lancar sebesar Rp.45.939.435.597,70 dikurangi persediaan sebesar Rp.5.705.242.184,00 dibandingkan dengan utang lancar sebesar Rp.14.716.194.591,17 dikali 100\% sehingga rasio lancar menjadi 2,73\%, untuk tahun 2016 aset lancar sebesar Rp.68.487.642.904,95 dikurangi persediaan sebesar Rp.5.683.327.333,00 dibandingkan dengan utang lancarnya meningkat sebesar Rp.35.619.117.459,41 dikali 100\%, sehingga rasio cepat menjadi 1,76\%.

\section{b. Rasio Solvabilitas}

Rasio solvabilitas digunakan untuk melihat kemampuan pemerintah daerah dalam memenuhi seluruh kewajibannya baik kewajiban jangka pendek maupun jangka panjang.

$$
\begin{gathered}
\text { Tahun } 2015=\frac{1 \cdot 296 \cdot 181 \cdot 887.836,89}{14.792 .479 .086,71} \times 100 \%=87,62 \% \\
\text { Tahun } 2016=\frac{1.507 .670 .106 .959,21}{6} \times 100 \%=21,77 \%
\end{gathered}
$$

69.243.645.624,95

Berdasarkan data diatas terlihat bahwa untuk tahun 2015 total aset pemerintah daerah sebesar Rp.1.296.181.887.836,89 dibandingkan dengan total utang sebesar Rp.14.792.479.086,71 dikali 100\% sehingga rasio solvabilitas menjadi 87,62\%, untuk tahun 2016 total aset pemerintah daerah sebesar Rp.1.507.670.106.959,21 dibandingkan dengan total utang sebesar Rp.69.243.645.624,95 dikali 100\% sehingga rasio solvabilitas menjadi 21,77\%.

\section{c. Rasio Utang (Leverage)}

Rasio utang digunakan untuk mengukur kemampuan pemerintah daerah dalam membayar utangnya. Rasio utang Pemerintah Daerah Kabupaten Konawe dihitung dengan menggunakan rasio sebagai berikut:

a) Rasio Utang Terhadap Ekuitas (Debt To Equity Ratio)

Rasio ini digunakan untuk mengetahui bagian dari setiap rupiah ekuitas dana yang dijadikan jaminan untuk keseluruhan utang. Rasio ini dihitung dengan rumus sebagai berikut:

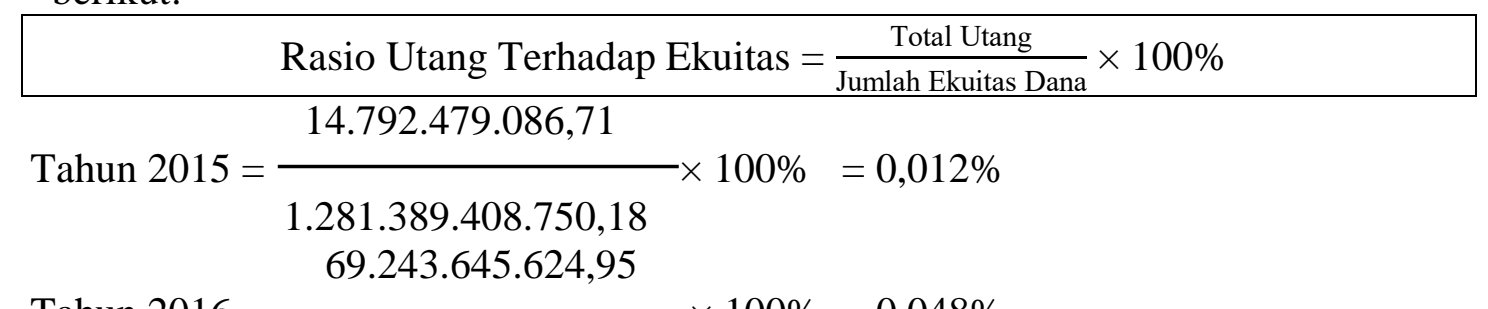

$$
\text { Tahun } 2016=\frac{}{1.438 .426 .461 .334,26} \times 100 \%=0,048 \%
$$

Berdasarkan data diatas terlihat bahwa untuk tahun 2015 total utang pemerintah daerah sebesar Rp.14.792.479.086,71 dibandingkan dengan ekuitas sebesar Rp.1.281.389.408.750,18 dikali $100 \%$ sehingga rasio utang terhadap ekuitas menjadi 0,012\%, untuk tahun 2016 total utang pemerintah daerah sebesar Rp.69.243.645.624,95 dibandingkan dengan ekuitas sebesar Rp.1.438.426.461.334,26 dikali 100\% sehingga rasio utang terhadap ekuitas menjadi 0,048\%.

b) Rasio Utang Terhadap Aset Modal (Debt To Aset Ratio)

Rasio ini digunakan untuk mengetahui berapa bagian dari aset modal yang digunakan untuk menjamin utang. Aset modal dalam hal ini diproksikan dengan aset tetap. Rasio ini dihitung dengan rumus sebagai berikut: 


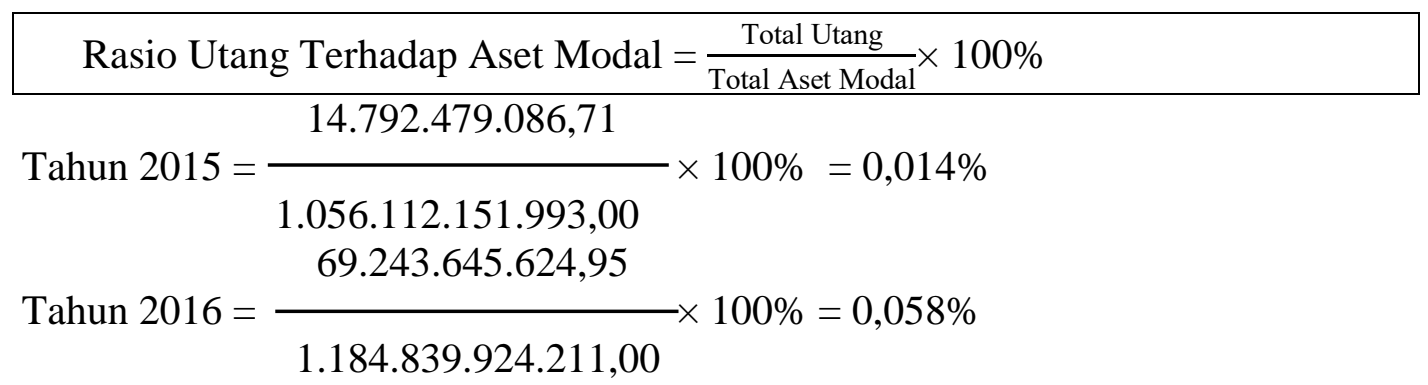

Berdasarkan data diatas terlihat bahwa untuk tahun 2015 total utang pemerintah daerah sebesar Rp.14.792.479.086,71 dibandingkan dengan aset modal sebesar Rp.1.056.112.151.993,00 dikali 100\% sehingga rasio utang terhadap aset modal menjadi 0,014\%, untuk tahun 2016 total utang pemerintah daerah sebesar Rp.69.243.645.624,95 dibandingkan dengan aset modal sebesar Rp.1.184.839.924.211,00 dikali 100\% sehingga rasio utang terhadap aset modal menjadi $0,058 \%$.

\section{d. Rasio Kemandirian Keuangan Daerah}

Analisis rasio kemandirian yaitu rasio yang digunakan untuk membandingkan pendapatan asli daerah dengan dana transfer dari pemerintah pusat maupun provinsi. Tingkat Kemandirian Pemerintah kabupaten Konawe tahun anggaran 2015-2016 dapat dilihat sebagai berikut:

$$
\begin{aligned}
& \text { Rasio Kemandirian Daerah }=\frac{\text { Pendapatan Asli Daerah }}{\text { Transfer Pusat + Provinsi + Pinjaman }} \times 100 \% \\
& \text { Tahun } 2015=\frac{63.542 .562 .780,78}{936.708 .171 .365,18} \times 100 \% \\
& =6,78 \% \\
& \text { Tahun } 2016=\frac{61.759 .220 .694,82}{1.028 .701 .068 .658,00} \times 100 \% \\
& =6,00 \%
\end{aligned}
$$

Dari tabel 4.12 diatas terlihat bahwa Kemandirian Daerah Pemerintah Kabupaten Konawe dalam mencukupi kebutuhan pembiayaan untuk melakukan tugas-tugas pemerintahan dan pelayanan sosial masyarakat masih rendah sekali. Rasio kemandirian kabupaten Konawe hanya berkisar $6,16 \%$ dan 6,00\%. Hal ini menunjukkan tingkat kemandirian kabupaten konawe rendah sekali dengan pola hubungan yang instruktif, dimana peranan pemerintah pusat lebih dominan daripada kemandirian pemerintah daerah (daerah yang tidak mampu melaksanakan otonomi daerah secara finansial).

\section{e. Rasio Ketergantungan Keuangan Daerah}

Tingkat Ketergantungan Keuangan Daerah Kabupaten Konawe tahun anggaran 20152016 dalam skala yang cukup besar terhadap pemerintahan pusat, karena berada dalam skala interval antara 10,01 - 20,00 \% yaitu rata-rata sebesar 15,7\% dan ini berarti bahwa Pendapatan Asli Daerah (PAD) mempunyai tingkat ketergantungan yang cukup besar untuk membiayai pengeluaran langsung, hal ini terjadi karena Pendapatan Asli Daerah (PAD) Kabupaten Konawe masih rendah.

$$
\text { Rasio Ketergantungan Keuangan Daerah }=\frac{\text { Pendapatan Trransfer }}{\text { Total Pendapatan Daerah }} \times 100 \%
$$




$$
\begin{aligned}
\text { Tahun } 2015 & =\frac{936.708 .171 .365,18}{63.542 .562 .780,78} \times 100 \% \\
& =\begin{array}{l}
14,74 \% \\
1.028 .701 .068 .658,00
\end{array} \\
\text { Tahun } 2016 & =\frac{61.759 .220 .694,82}{16,66 \%}
\end{aligned}
$$

Dari table 4.13 diatas terlihat bahwa Ketergantungan Ketergantungan Keuangan Daerah pada tahun anggaran pemerintahan Kabupaten Konawe dalam skala yang cukup besar terhadap pemerintahan pusat, karena berada dalam skala interval antara 10,01 - 20,00\% yaitu rata-rata sebesar $15,7 \%$ dan ini berarti bahwa Pendapatan Asli Daerah (PAD) mempunyai tingkat ketergantungan yang cukup besar untuk membiayai pengeluaran langsung, hal ini terjadi karena Penadapatan Asli Daerah (PAD) Kabupaten Pamekasan masih rendah.

\section{Pembahasan Hasil Penelitian}

Berdasarkan hasil penelitian yang disajikan pada tabel 4.10 analisis rasio keuangan Pemerintah Daerah Kabupaten Konawe dapat dilihat dibawah ini.

\section{a. Rasio Likuiditas}

Rasio likuiditas adalah kemampuan pemerintah daerah untuk melunasi kewajiban jangka pendeknya dengan menggunakan aset lancarnya. Rasio likuiditas diukur menggunakan rasio lancar (current ratio), rasio kas (casht ratio) dan rasio cepat (quick ratio).

Berdasarkan hasil analisa rasio likuiditas (kemampuan pemerintah daerah dalam memenuhi kewajiban jangka pendeknya dengan menggunakan aset lancarnya) Pemerintah Daerah Kabupaten Konawe pada tahun 2016 mengalami penurunan untuk semua nilai rasio. Angka persentase penurunan rasio ini kurang baik meskipun tidak melewati $100 \%$ artinya Pemerintah Daerah Kabupaten Konawe sedang dalam keadaan kurang liquid. Penyebab penurunan tersebut karena pada tahun 2016 jumlah utang lancar lebih tinggi yaitu sebesar142,04\%. Kenaikan tersebut dikarenakan: Pertama, mutasi penambahan Utang Perhitungan Fihak Ketiga (PFK) yang merupakan realisasi jumlah pemungutan pajak dari PFK Bendahara Pengeluaran SKPD, pungutan PFK pada BUD, pungutan PFK Bendahara BLUD dan pungutan PFK pada bendahara FKTP selama Tahun 2016. Kedua, Utang Beban Pemerintah Daerah Kabupaten Konawe per 31 Desember 2016 sebesar Rp108.077.105,00 atas pinjaman jatuh tempo PT.Sarana Multi Infrastruktur (SMI). Ketiga, Utang beban sebesar Rp248.156.109,00 timbul karena Pemerintah Kabupaten Konawe menikmati jasa listrik pada periode bulan Desember 2016 namun belum melakukan pembayaran atas jasa listrik tersebut per 31 Desember 2016, pemerintah harus mengakui hutang atas jasa listrik yang belum dibayarkan tersebut. Keempat, Utang Jangka Pendek Lainnya yang merupakan kewajiban Kabupaten Konawe kepada pihak ketiga yaitu utang kepada Kabupaten Konawe Kepulauan, utang kepada pihak ketiga /rekanan dan utang belanja gaji kepada PNS (gaji kekurangan). Kelima, Utang Badan Layanan Umum Daerah (BLUD) yang merupakan biaya jasa hasil pelayanan yang masih harus dibayar kepada tenaga medis dan paramedis.

\section{b. Rasio Solvabilitas}

Rasio solvabilitas digunakan untuk melihat kemampuan pemerintah daerah dalam memenuhi seluruh kewajibannya baik kewajiban jangka pendek maupun jangka panjang. Rasio ini disarankan harus berada diatas $100 \% 1$ : 1 jika rasio likuiditasnya kurang dari 1: 1 atau 100\% maka keuangan pemerintah daerah dianggap kurang solvabel. 
Berdasarkan hasil analisa rasio solvabilitas (kemampuan pemerintah daerah dalam memenuhi seluruh kewajiban baik jangka pendek maupun jangka panjang dengan menggunakan total asetnya) Pemerintah Daerah Kabupaten Konawe pada tahun 2015-2016 mengalami penurunan sebesar 65,85\% . Penurunan tersebut dikarenakan pada tahun 2016 total kewajiban lebih tinggi dibandingkan total aset. Kenaikan tersebut didominasi oleh peningkatan kewajiban jangka panjang yang mencapai 43.977,80\%. Utang Jangka Panjang sebesar Rp 33.624.528.165,54 merupakan pembayaran Fasilitas Pembiayaan Tahap pertama (Uang Muka) pinjaman jangka panjang dari total pinjaman sebesar Rp.231.974.000.000,00 dengan jangka waktu pengembalian selama 8 (delapan) tahun pada PT. Sarana Multi Infrastruktur (SMI). Fasilitas pembiayaan tersebut digunakan untuk keperluan pekerjaan pembangunan Rumah Sakit Umum Daerah Kabupaten Konawe.

\section{c. Rasio Utang (Leverage)}

Rasio utang digunakan untuk mengukur kemampuan pemerintah daerah dalam membayar utangnya. Rasio utang Pemerintah Daerah Kabupaten Konawe dihitung dengan menggunakan rasio utang terhadap ekuitas (Debt To Equity Ratio) dan rasio utang terhadap aset modal (Debt To Aset Ratio).

a) Rasio Utang Terhadap Ekuitas (Debt To Equity Ratio)

Rasio ini digunakan untuk mengetahui bagian dari setiap rupiah ekuitas dana yang dijadikan jaminan untuk keseluruhan utang. Berdasarkan hasil analisis data terlihat bahwa pada tahun 2015 rasio utang terhadap ekuitas Pemerintah Daerah Kabupaten Konawe sebesar 0,012 : 1 artinya setiap Rp.1,- utang dapat dijamin dengan menggunakan ekuitas yang dimiliki pemerintah daerah sebesar $0,012 \%$ dan pada tahun 2016 rasio utang terhadap ekuitas mengalami peningkatan sebesar 0,048: 1 artinya setiap Rp.1,- utang dijamin dengan menggunakan ekuitas yang dimiliki pemerintah daerah sebesar $0,048 \%$. Walaupun terjadi sedikit peningkatan namun besaran rasio tersebut masih relatif sangat kecil sehingga masih dalam batas aman.

b) Rasio Utang Terhadap Aset Modal (Debt To Asset Ratio)

Rasio ini digunakan untuk mengetahui bagian dari aset modal yang dapat digunakan untuk menjaminan utang. Berdasarkan hasil analisis data terlihat bahwa pada tahun 2015 rasio utang terhadap aset modal Pemerintah Daerah Kabupaten Konawe sebesar 0,014 : 1 artinya setiap Rp.1,- utang dapat dijamin dengan menggunakan ekuitas yang dimiliki pemerintah daerah sebesar 0,014\% dan pada tahun 2016 rasio utang terhadap aset modal mengalami peningkatan sebesar 0,058 : 1 artinya setiap Rp.1,utang dijamin dengan menggunakan ekuitas yang dimiliki pemerintah daerah sebesar $0,058 \%$. Walaupun terjadi sedikit peningkatan namun besaran rasio tersebut masih relatif sangat kecil sehingga masih dalam batas aman.

\section{d. Rasio Ketergantungan Keuangan Daerah}

Hasil penelitian memberikan gambaran bahwa Pemerintah Daerah Kabupaten Konawe tidak memiliki PAD yang cukup besar untuk membiayai APBD-nya. Kontribusi terbesar pendapatan Pemerintah Daerah Kabupaten Konawe tahun anggaran 2015-2016 berasal dari Dana Transfer sedangkan PAD hanya memberikan kontribusi yang relative kecil. Hal ini menunjukkan bahwa masih rendahnya kemandirian keuangan Kabupaten Konawe dalam mencukupi kebutuhan pembiayaan untuk melakukan tugas-tugas pemerintahan, pembangunan dan pelayanan masyarakat.

Kemandirian keuangan daerah ditunjukkan oleh besar kecilnya Pendapatan Asli Daerah dibandingkan dengan pemerimaan daerah. Tingkat kemandirian menggambarkan tingkat partisipasi masyarakat dalam membayar pajak dan retribusi daerah yang merupakan 
komponen utama dalam Pendapatan Asli Daerah. Analisis kemandirian keuangan daerah yang dilakukan terhadap Laporan Operasional Pemerintah Daerah Kabupaten Konawe tahun anggaran 2015-2016, bertujuan untuk mengetahui pola hubungan pemerintah pusat dengan pemerintah daerah serta kemampuan keuangannya.

\section{e. Rasio Ketergantungan Keuangan Daerah}

Rasio ketergantungan keuangan daerah Kabupaten Konawe tahun anggaran 20152016 dalam skala yang cukup besar terhadap pemerintahan pusat, karena berada dalam skala interval antara 10,01 - 20,00\% yaitu rata-rata sebesar $15,7 \%$ dan ini berarti bahwa Pendapatan Asli Daerah (PAD) mempunyai tingkat ketergantungan yang cukup besar untuk membiayai pengeluaran langsung, hal ini terjadi karena Penadapatan Asli Daerah (PAD) Kabupaten Konawe masih rendah.

Hasil penelitian menunjukkan bahwa tingkat ketergantungan Kabupaten Konawe tahun anggaran 2015 sebesar 14,76\% dan tahun 2016 sebesar 16,66\%. Hal ini menunjukkan bahwa pola hubungan antara pemerintah pusat dengan pemerintah daerah serta kemampuan keuangan Pemerintah Daerah Kabupaten Konawe pada pola tingkat ketergantungan berada dikisaran 10,01\%-20,00\%. Untuk mengurangi ketergantungan pada pemerintah pusat/provinsi maka perlu adanya usaha untuk mengoptimalkan sumber pendapatan yang telah ada seperti pajak daerah dan retribusi daerah dengan cara pemerintah daerah harus lebih tegas dan agresif dalam mengumpulkan pajak dan retribusi daerah serta mampu meminta wewenang yang lebih luas untuk mengelola sumber pendapatan lain yang sampai saat ini masih dikuasai oleh pemerintah pusat misalnya pemerintah daerah meminta wewenang untuk mengelola Sumber Daya Alamnya sendiri seperti sumber daya hutan dan pungutan hasil perikanan.

\section{KESIMPULAN DAN SARAN}

Berdasarkan hasil penelitian dan pembahasan yang telah diuraikan sebelumnya, maka dapat ditarik kesimpulan sebagai berikut:

1) Rasio Likuiditas Pemerintah Daerah Kabupaten Konawe tahun anggaran 2015-2016 dalam kategori baik artinya semakin tinggi nilai rasionya semakin baik, walaupun terjadi penurunan untuk semua nilai rasio pada tahun 2016, tetapi nilainya masih diatas rata-rata industri, artinya keuangan Pemerintah Daerah Kabupaten Konawe dikategorikan likuid.

2) Rasio solvabilitas Pemerintah Daerah Kabupaten Konawe tahun anggaran 2015-2016 dalam kategori baik artinya semakin tinggi nilai rasionya semakin baik, walaupun ditahun 2016 terjadi penurunan tetapi keuangan Pemerintah Daerah Kabupaten Konawe masih dalam keadaan likuid dan solvabel.

3) Rasio Utang Pemerintah Daerah Kabupaten Konawe tahun 2015-2016 dikategori baik artinya semakin besar rasio ini menunjukkan risiko pemberian utang semakin besar, walaupun terjadi peningkatan nilai rasio ditahun 2016 namun nilainya relatif masih sangat kecil.

4) Rasio ketergantungan keungan daerah untuk membiayai pengeluaran Langsung daerah ratarata sebesar 15,7\%, ini artinya ketergantungan di Kabupaten Konawe cukup besar, karena masih berada dalam skala interval antara 10,01 - 20,00 \% . Hal ini berarti Pendapatan Asli Daerah (PAD) memiliki ketergantungan cukup besar untuk membiayai pengeluaran langsungnya dan pemerintah Kabupaten Konawe masih tergantung pada sumber penerimaan keuangan dari transfer pemerintah pusat dan provinsi.

Berdasarkan hasil analisis dan pembahasan yang telah dilakukan, maka penulis memberikan saran sebagai berikut: 
1) Pemerintah Daerah Kabupaten Konawe melakukan efisiensi dalam penggunaan anggaran daerah dan lebih fokus penggunaan anggaran untuk investasi sehingga dapat menambah aset pemerintah daerah seperti investasi dalam pembangunan infrastruktur sehingga dapat meningkatkan kinerja pemerintah dalam memberikan pelayanan yang lebih baik kepada masyarakat.

2) Untuk peneliti selanjutnya, yang ingin melakukan penelitian tentang kinerja keuangan pemerintah daerah dapat melakukan penelitian dengan menambah variabel lain seperti rasio efektivitas, rasio efisiensi dan rasio ekonomi dalam menilai tingkat kinerja keuangan agar memperoleh ruang lingkup yang lebih luas.

\section{DAFTAR PUSTAKA}

Bastian, Indra. 2010. Akuntansi sektor Publik; Suatu Pengantar. Jakarta: Penerbit Erlangga.

Batafor, Gregorius Gebi. 2011. Evaluasi Kinerja Keuangan dan Tingkat Kesejahteraan Masyarakat Kabupaten Lembat: Jurnal.

Darise, Nurlan. 2009. Pengelola Keuangan Daerah Edisi II. PT. Indeks. Jakarta

Erliana dan Rasdianto. 2013. Akuntansi Keuangan Daerah Berbasis Akrual. Medan: Brama Ardian.

Erlina, Omar dan Rasdianto. 2015. Akuntansi Keuangan Daerah, Berbasis Akrual Jakarta: Penerbit Salemba Empat.

Fathiyah dan Mahsun. 2017. Analisis Kinerja Keuangan Pemeerintah Provinsi Jambi Pada Laporan Keuangan Pemerintah Daerah Sebelum dan Sesudah Diterapkannya Basis Akrual Tahun Anggaran 2014-2015. Universitas Batanghari.

Halim, Abdul. 2001 Akuntansi Sektor publik-Akuntansi keuangan Daerah. Jakarta: Salemba Empat.

2007. Akuntansi Sektor Publik Keuangan Daerah. Edisi ketiga: Penerbit Salemba Empat. Jakarta.

Harahap, Sofyan Syarif. 2009. Analisis Kritis Atas Laporan Keuangan. Jakarta: Raja Grafindo Persada

Kasmir. 2008. Analisis Laporan Keuangan. Jakarta: RajawaliPers

Mahsun, Mohammad. 2016. Pengukuran Kinerja Sektor Publik. Edisi pertama Yogyakarta: BPFE.

Mahsun, Sulistiyowati dan Andre. 2012 Akuntansi Sektor Publik. Edisi ketiga. Yogyakarta: BPFE

Mahmudi. 2011. Akuntansi Sektor Publik. Yogyakarta: UII Press.

Mahmudi. 2016. Analisis Laporan Keuangan Pemerintah Daerah. Edisi Ketiga. Yogyakarta: UPP STIM YKPN

Mardiasmo. 2002, Otonomi dan Manajemen Keuangan Daerah. Yogyakarta: ANDI 2009. Akuntansi Sektor Publik. Yogyakarta:ANDI

Nurhayati. 2016 “Analisis Laporan Keuangan Untuk Mengukur Kinerja Keuangan Pemerintah Daerah Kabupaten Rokan Hulu Tahun Anggaran 2010-2014. Universitas Pasir Pangairan

Peraturan Pemerintah Dalam Negeri Nomor 64 Tahun 2013 tentang Standar Akuntansi Pemerintahan Berbasis Akrual.

Peraturan Pemerintah Nomor 71 Tahun 2010 Tentang Standar Akuntansi Pemerintahan.

Prastowo, Dwi dan Juliaty, Rifka. 2008. Analisis Laporan Keuangan. Edisi Kedua. UPP STIMYKPN. Yogyakarta.

Robertson, Gordon. (2002). "revie kinerja" lokakarya revie kinerja. BPKP dan Eksekutif Education. 
Jurnal Akuntansi dan Keuangan Volume V/1/Februari 2020

ISSN (Online) : 2503-1635, ISSN (Print): 2088-4656

Simamora, Hanry. 2010. Manajemen Sumber Daya Manusia. Yogyakarta: STIEE YKPN.

Sugiyono. 2009. Metode Penelitian Bisnis. Bandung: Alfabeta.

Undang-Undang Nomor 17 Tahun 2003 tentang Keuangan Negara.

Widjaja, 2001. Titik Berat Otonomi Daerah Tingkat II. Cetakan Keempat. Devisi Buku. Jakarta. Perguruan Tinggi Raja Grapindo. Jakarta.

Widjajarso, Bambang. 2008. Penerapan Basis Akrual Pada Akuntansi Pemerintahan Indonesia: Sebuah Kajian Pendahuluan.

Wiratna Sujarweni, 2014. Metodologi Penelitian. Yogyakarta: PT. Pustaka Baru.

Yusuf, Mohammad. 2010. Langkah Pengelolaan Aset Menuju Pengelolaan Keuangan Daerah Terbaik. Jakarta: Salemba Empat. 